\title{
Screening of chickpea (cicer arietinum 1.) genotypes for earliness, yield, yield components and resistance against fusarium wilt
}

\author{
El - Garhy, A. M. ${ }^{1}$ and Rahhal, M. M. H. ${ }^{2}$ \\ 1- Food Legumes Crop Research Section, Field Crop Research Institute, ARC, Egypt. \\ ${ }^{2}$-Plant Pathology Research Institute, ARC, Egypt.
}

\begin{abstract}
Twelve chickpea ( Cicer arietinum L.) genotypes were evaluated for earliness, yield, yield components and resistance against fusarium wilt under field and laboratory conditions through two successive seasons; 2009/2010 and 2010/2011. Under field conditions, generally for both seasons, L 138 had the first grade in case of number of days for flowering (earliness), number of days for maturity, seed weight / plant (g), 100 seed weight (g) and seed yield / feddan (ardab). Also, the four Egyptian genotypes (Giza 88, Giza 1 and 2 and L 138) had better values than the eight ICARDA genotypes for the parameters mentioned before. At the first season the least total fusarium wilt for both seedling and podding stages were noticed in case of L 138 followed by G88 and F $97-195 \mathrm{C}$ with averages of $11.52,12.78$ and $15.65 \%$, respectively. At the second season it was the least with L 138 followed by F $97-195$ C, G 88 and F $98-58$ C with averages of 8.36, 9.55, 11.88 and 12.80\%, respectively. Under laboratory conditions, chickpea genotypes leaf extracts (CLE) decreased Fusarium oxysporum f.sp. ciceris linear growth than chickpea genotypes root extracts ( CRE ) with averages of 3.79 and $5.88 \mathrm{~cm}$., respectively. The least linear growth in case of (CLE) cleared with L 138 and F $97-195$ C with averages of 2.05 and $2.53 \mathrm{~cm}$., respectively but F $98-58 \mathrm{C}$ had the highest value with an average of $4.84 \mathrm{~cm}$. Using CRE, also L 138 and F $97-195$ C had the best effect in reducing the fungal linear growth with averages of 2.86 and $3.62 \mathrm{~cm}$. respectively.
\end{abstract}

Keywords: chickpea, Cicer arietinum, genotypes, fusarium wilt, earliness

\section{Introduction}

Chickpea ( Cicer arietinum L. ) is the third most important food legume grown annually on an area of about $10 \mathrm{~m}$ ha in about 50 contries and over $95 \%$ of its production and consumption is in the developing contries ( FAOSTAT data, 2006 ). Its pulses have $11-28 \%$ proteins depending on the variety, $3 \%$ fiber, $3 \%$ ash, $4.8-5.5 \%$ oil, $38-59 \%$ carbohydrate, 0.3 $\%$ phosphorus and $0.2 \%$ calcium ( Hulse, 1991; Huisman and Vanderpoel, 1994; Bhatti and Soomro, 1996 and Emenky and Khalaf, 2008 ). Although chickpea can fix up to $140 \mathrm{~kg} \mathrm{~N} \mathrm{ha}^{-1}$ in growing season, reported values usually range from 20 to 60 kg N ha ${ }^{-1}$ ( Ryan, 1997 ).

The crop cycle in most of its traditional growing areas is completely different from the autumn germination, spring flowering and summer maturity. Reduced crop duration may also help chickpea escape damage by the major biotic- and abiotic stress that mostly affect the crop at flowering and podding stages (Kumar et al., 1996; Johansen et al., 1997 and Kumar and Abbo 2001). Also, Sabaghpour et al. (2003 and 2006) reported that, selection for early maturity chickpea line is the most important objective for escaping terminal drought stress which is the major abiotic stress for reducing chickpea productivity. In this respect, Kumar et al. (1996) mentioned that chickpea growing season is generally too longer for obtaining meagre mean seed yield of about $0.8 \mathrm{t} \mathrm{ha}^{-1}$ and this could be produced in a much shorter period. Therefore, it is dangerous to let such an attractive crop remain in the field for longer period than is necessary.

Chickpea wilt caused by Fusarium oxysporum f.sp.ciceris is one of the major yield limiting factors in chickpea. The disease caused $10-90 \%$ yield losses annually (Sharma and Muehlbauer, 2007). The pathogen is facultative saprophyte and can survive in soil up to six years in the absence of susceptible host ( Haware et al., 1986 a and b ). Earlier wilting caused more loss than late wilting and seeds harvested from wilted plants were lighter and duller than those from healthy plants ( Haware and Nene, 1980 ). In this respect, Navas - Corte's et al. (2000) reported that fusarium wilt reduced chickpea yield by decreasing both seed yield and seed weight. Considering the nature of damage and survival ability of the fungus, use of resistant varieties is the only economical and practical solution (Nene and Haware, 1980; Bakhsh et al., 2007 and Mahmood et al., 2011). So, Chaudhry et al. (2007) reported that progress has been made in identifying sources of resistance to wilt disease of chickpea through screening of germplasm and inheritance of the disease resistance, but Nikam et al. (2007) mentioned that most of the resistant varieties have been found to be susceptible after some years because of breakdown in their resistance and evolution of variability in the pathogen. 
The present study is directed for screening of some chickpea genotypes for earliness, yield and resistance against fusarium wilt for escaping from drought stress and fusarium wilt which cause yield losses.

\section{Materials and methods}

Chickpea genotypes for the screening of earliness and resistance against fusarium wilt were acquired from Food Legume Research Section, Field Crop Res. Inst. ARC, Giza, Egypt named Giza 88, Giza 1, Giza 2 and L 138 and from ICARDA, Allepo, Syria named F 95 - 14 C, F 98 - 79 C, F 98 - 233 C, F 97 - 195 C, F 97 - 167 C, F 97 - 14 C, F 98 - 173 C and $\mathrm{F} 98-58 \mathrm{C}$.

\section{Field Experiments:}

The experiments were conducted through two successive seasons; 2009 / 2010 and 2010 / 2011 at Etay El - Baroud Agric. Res. Station, Behera Governorate. Twelve genotypes mentioned before were sown in 22/11/2009 and 25/11/2010 for the first and second seasons, respectively. The experimental layout was randomized complete block design (RCBD) with three replications. The area of each experimental unit was $5.4 \mathrm{~m}^{2}$, consisting of three ridges of $3 \mathrm{~m}$ in length and $0.60 \mathrm{~m}$ in between. Seeds were sown in hills of $20 \mathrm{~cm}$ aparte in two sides/ ridge with 2 seeds / hill.

Fusarium wilt disease which naturally happened by Fusarium oxysporum was assessed at the seedling and podding stages after 30 and 120 days from sowing, respectively. The percentage of wilt incidence of each genotype was calculated and the disease reaction ( DR ) was determined using ( $1-9$ ) disease rating scale given by Iqbal et al.(2005), where 1: highly resistance ( $0-10 \%$ plant wilted ), 3: resistant ( $11-20 \%$ plants mortality ), 5: moderately resistance ( $21-30 \%$ mortality ), 7 : susceptible ( $31-50 \%$ mortality ) and 9: highly susceptible ( more than $50 \%$ mortality ). Disease incidence was calculated using the following formula:

Wilt incidence $=($ Number of wilted plants $/$ Total number of plants) X 100

The number of days to $50 \%$ flowering and 90 $\%$ maturity were recorded. At harvesting the following agronomic parameters were determined: plant height (cm.), number of branches / plant, number of capsules / plant, seed weight (g.) / plant, 100 seed weight (g.) and seed yield / feddan (ardab).

\section{Laboratory Experiments:}

1-Isolation, purification and identification of Fusarium oxysporum f.sp.ciceris:

The infected portions of stem and root were cut into one $\mathrm{cm}$. small pieces. These were surface sterilized with $2.5 \%$ sodium hypochlorite for a minute then rinsed in sterilized distilled water, blottered and plated on PDA medium on $9 \mathrm{~cm}$. Petri dishes and incubated at $23^{\circ} \mathrm{C}$ for 7 days ( Elfatih et al., 2002 ). Identification was carried out with the help of (Haware et al., 1992; Barhate et al., 2006 and Ahmad, 2010).

\section{2 - Effect of chickpea leaf and root extract on fungal growth:}

In order to study the role of plant extract of different chickpea genotypes on the growth of $F$. oxysporum f. sp. ciseris, 5 g. shoot tips and roots of each genotype were dipped in $100 \mathrm{ml}$ distilled water and sieved after two hours through whatman No. 1 filter paper (Ahmad, 2010). The filtrates were vaccum filtered through sterile $0.2 \mu \mathrm{m}$ filters (Syborn / Nalgen Co., Rochesterr NY). Sterilized dextrose water agar medium (DWA $2 \%$ ) was mixed with 10 $\mathrm{ml}$ water extract and poured in Petri dishes $(9 \mathrm{~cm}$.). After cooling, media were inculated with $5 \mathrm{~mm}$ margins mycelia plug of a 7 - day - old culture of F.oxysporum f.sp.ciceris and incubated at $26 \pm 2^{\circ} \mathrm{C}$ (Iqbal et al., 2005). The experiment conducted with four replicates and the fungal linear growth was taken 7 days after incubation.

\section{Statistical Analysis:}

Data were statistical analyzed according to Snedecor and Cochran (1981). Treatment means were compared by L.S.D. at $5 \%$ level of probability.

\section{Results and discussion}

During chickpea growth duration, days for $50 \%$ flowering and $90 \%$ physiological maturity were calculated and at the end of the experiment some agronomic parameters were estimated. From results in Table (1) it is clear that, L 138 had the less number of days to $50 \%$ flowering followed by F $97-195 \mathrm{C}$ and $\mathrm{G} 88$ with averages of 56.0, 63.0 and 67.7 days, respectively. Also, L 138 had lesser number of days for $90 \%$ maturity with average of 132.0 day than the other genotypes which ranged from 141.3 to 144.0 days. Also, it can be noticed that the Egyptian genotypes had better averages (71.13 and 139.65 days) than ICARDA genotypes (74.03 and 142.18 days) in case of days for flowering and maturity. The differences between genotypes in the timing of flowering are in agreement with the findings of Worland (1996) who reported that the timing of flowering is dependent upon the genotype, the seasonal temperature profile, photoperiod and vernalization responses of plant. Also, Kumar and Abbo (2001) mentioned that the flowering time of chickpea genotype varies with latitude and temperature variation, thus the genes controlling flowering time are sensitive to temperature and day length. At the end of the experiment, plant height $(\mathrm{cm}$.$) , number of branches/plant, number of$ capsules/plant, seed weight/plant (g), 100 seed weight $(\mathrm{g})$ and seed yield/feddan (ardab) were 
determined (Table 1). Data show that genotypes; $\mathrm{F}$ 98 - 173 C, L 138, F 98 - 233 C and F $97-14$ C had the highest values of plant height $(\mathrm{cm}$.) with averages of $61.9,59.5,57.2$ and $57.2 \mathrm{~cm}$., respectively. In case of number of branches / plant

Table 1. Agronomic traits of twelve chickpea (Cicer arietinum L.) genotypes under field conditions (first season, 2009 / 2010).

\begin{tabular}{|c|c|c|c|c|c|c|c|c|}
\hline $\begin{array}{l}\text { Parameter } \\
\text { Genotype }\end{array}$ & $\begin{array}{l}\text { Days for } \\
\text { flowering }\end{array}$ & $\begin{array}{l}\text { Days for } \\
\text { maturity }\end{array}$ & $\begin{array}{l}\text { Plant } \\
\text { height } \\
(\mathrm{cm} .)\end{array}$ & $\begin{array}{l}\text { No.of } \\
\text { branches } \\
\text { / } \\
\text { plant }\end{array}$ & $\begin{array}{l}\text { No.of } \\
\text { capsules/ } \\
\text { plant }\end{array}$ & $\begin{array}{l}100- \\
\text { seed } \\
\text { Weight/ } \\
\text { Plant (g) }\end{array}$ & $\begin{array}{l}\text { Seed } \\
\text { weight/ } \\
\text { Plant (g) }\end{array}$ & $\begin{array}{l}\text { Seed } \\
\text { yield/ } \\
\text { feddan } \\
\text { (ardab) }\end{array}$ \\
\hline G 88 & 67.7 & 142.0 & 44.5 & 0.55 & 9.80 & 22.90 & 4.46 & 4.84 \\
\hline G 1 & 81.8 & 142.3 & 49.8 & 1.10 & 38.17 & 16.79 & 7.92 & 4.30 \\
\hline G 2 & 79.0 & 142.3 & 45.3 & 0.75 & 15.05 & 21.06 & 4.42 & 4.13 \\
\hline L 138 & 56.0 & 132.0 & 59.5 & 1.15 & 16.70 & 24.90 & 11.15 & 5.32 \\
\hline F $95-14 \mathrm{C}$ & 71.8 & 141.8 & 49.4 & 1.55 & 22.77 & 24.53 & 6.46 & 3.55 \\
\hline F $98-79$ C & 71.8 & 141.8 & 55.2 & 1.65 & 33.30 & 21.59 & 8.95 & 3.86 \\
\hline F $98-233$ C & 77.0 & 141.3 & 57.2 & 2.00 & 35.60 & 19.44 & 6.76 & 4.02 \\
\hline F $97-195$ C & 63.0 & 143.0 & 55.7 & 2.65 & 22.60 & 17.22 & 9.55 & 4.54 \\
\hline F $97-167$ C & 79.0 & 144.0 & 51.5 & 2.10 & 48.55 & 16.30 & 7.84 & 3.81 \\
\hline F $97-14 \mathrm{C}$ & 78.3 & 141.7 & 57.2 & 1.50 & 36.05 & 17.79 & 6.83 & 3.60 \\
\hline F $98-173$ C & 77.3 & 141.3 & 61.9 & 1.00 & 39.60 & 19.43 & 8.84 & 4.48 \\
\hline F $98-58$ C & 74.0 & 142.5 & 55.4 & 2.00 & 16.20 & 20.61 & 5.70 & 5.31 \\
\hline L.S.D. 0.05 & 3.05 & 7.96 & 2.24 & 0.31 & 3.30 & 1.47 & 0.75 & 0.59 \\
\hline
\end{tabular}

it is clear that F $97-195 \mathrm{C}, \mathrm{F} 97-167 \mathrm{C}, \mathrm{F} 98-233$ $\mathrm{C}$ and $\mathrm{F} 98-58 \mathrm{C}$ had the highest values with averages of 2.65, 2.10, 2.00 and 2.00, respectively. On the other hand genotypes, F $97-167$ C, F $98-$ 173 and G 1 had more number of capsules / plant than the other genotypes with averages of 48.55, 39.60 and 38.17, respectively. In this respect G 88 had the lowest values for the previous three traits mentioned before. As it clear from this table, L 138 had the first grade for the seed weight / plant $(\mathrm{g})$ followed by F 97 - $195 \mathrm{C}$ and F98 - $79 \mathrm{C}$ with averages of $11.15,9.55$ and $8.95(\mathrm{~g})$, respectively. Also L 138 maintained the first grade in case of 100 seed weight ( $\mathrm{g}$ ) followed by F $95-14 \mathrm{C}$ and $\mathrm{G} 88$ with averages of $24.90,24.53$ and $22.90(\mathrm{~g})$, respectively. Finally the same trend was noticed with seed yield / feddan (ardab) where L 138 had the highest value followed by G 88 and F $97-167$ C with averages of 5.32, 4.84 and 4.54 ardab, respectively. The differences among the tested genotypes for their agronomic traits are in agreement with the findings of Bastawisy et al. (2008) who reported that this differences may be due to the presence of genetic variability in the genotypes. Or et al. (1999) focused on the importance of the earliness where they reported that in Mediterranean environment, early flowering might allow a longer reproduction period. Also, Johansen et al. (1997) mentioned that there was linear positive relationship between early crop growth and seed yield. Pathologically fusarium wilt play an important role in chickpea production where Navas - Corte's et al. (2000) reported that fusarium wilt reduced chickpea yield by decreasing both seed yield and seed weight. Also, Sandhu et al. (2007) mentioned that two super
- early chickpea breeding lines; ICCV96029 and ICCV96030 were found early in flowering and podding and produced $>2.0 \mathrm{t} \mathrm{ha}^{-1}$ fresh green seed yield, but the acceptability of these lines was restricted due to their susceptibility to disease. On the other hand, Elfatih et al . (2002) reported that because of ICCV2 resistance to fusarium wilt, its earlier maturity and its higher grain yield, it is a potential variety for release in the traditional chickpea producing area of Sudan. From the above table it can be noticed that Egyptian genotypes had seed weight/plant $(\mathrm{g}), 100$ - seed weight $(\mathrm{g})$ and seed yield/feddan (ardab) with range between 4.42 $11.15,16.79-24.90$ and $4.13-5.32$, respectively and ICARDA genotypes between $5.70-9.55,16.30$ -24.53 and $3.55-5.31$ for the same parameters, respectively.

Under field conditions, fusarium wilt incidence of seedling stage (30 days after sowing) was determined. Results in Table (2) clear that the chickpea genotypes appeared different wilt percentages and it ranged from 5.30 to $10.99 \%$. L 138 had the low wilt percentage followed by G $88, \mathrm{~F}$ $97-167$ C, F $95-14$ C and G 2 with averages of $5.30,5.48,5.74,6.13$ and $7.17 \%$, respectively. In contrast, F 98 - 233 had the highest value with an average of $10.99 \%$. When the wilt incidence was determined at the podding stage (120 days), L 138 had the lowest value followed by F $97-195$ C, G 88, F $98-173 \mathrm{C}$ and F $98-58 \mathrm{C}$ with averages of 6.22 , $7.77,8.30,8.99$ and $9.50 \%$. The disease reaction (DR) in the chickpea genotypes seedling stage was 1 except F $98-233 \mathrm{C}$ which was 3 , and in case of the podding stage ranged between 1 - 5 according to Iqbal et al. (2005). Generally, L 138 had the lower 
total wilt incidence followed by G 88 and F $98-195$ $\mathrm{C}$ with averages of $11.52,12.78$ and $15.65 \%$, respectively. The differences of the susceptibility between the two growth stages to fusarium wilt are in agreement with the findings of Ahmad et al. (2010) who evaluated 321 chickpea genotypes against fusarium wilt and they found that at seedling stage disease incidence varied from 0 to $29.3 \%$ whereas at reproductive stage ranged from 0 to $57 \%$. In this respect, they mentioned that at seedling stage the chickpea crop stand generally remain good due to sufficient moisture which favour the crop growth, thus there are loss chances of wilt / root rot disease. However, at the mid podding stage there are more chances of disease because of drought conditions and rise of temperature. It can be noticed that the wilt incidence of the Egyptian genotypes at seedling and podding stages range between $5.30-7.75 \%$ and $6.22-18.43 \%$, respectively, but in case of ICARDA genotypes it ranged from 5.74 to $10.99 \%$ and $7.77-$ $26.99 \%$, respectively.

Table 2. Disease incidences of fusarium wilt on various chickpea (Cicer arietinum L.) genotypes at two growth stages (field experiment 2009 / 2010).

\begin{tabular}{|c|c|c|c|c|c|}
\hline \multirow{3}{*}{ Genotype } & \multicolumn{4}{|c|}{ Disease incidence } & \multirow{3}{*}{ Total wilt $\%$} \\
\hline & \multicolumn{2}{|c|}{ Seedling stage } & \multicolumn{2}{|c|}{ Podding stage } & \\
\hline & Wilt \% & $\mathrm{DR}^{*}$ & Wilt \% & DR & \\
\hline G 88 & 5.48 & 1 & 8.30 & 1 & 13.78 \\
\hline G 1 & 7.75 & 1 & 18.43 & 3 & 26.18 \\
\hline G 2 & 6.17 & 1 & 17.03 & 3 & 23.20 \\
\hline L 138 & 5.30 & 1 & 6.22 & 3 & 11.52 \\
\hline F $95-14$ C & 6.13 & 1 & 13.09 & 5 & 19.22 \\
\hline F $98-79 \mathrm{C}$ & 9.52 & 1 & 21.41 & 5 & 30.93 \\
\hline F $98-233$ C & 10.99 & 3 & 26.99 & 1 & 37.98 \\
\hline F $97-195$ C & 7.88 & 1 & 7.77 & 3 & 15.65 \\
\hline F $97-167$ C & 5.74 & 1 & 11.99 & 5 & 17.73 \\
\hline F $97-14$ C & 9.64 & 1 & 22.67 & 1 & 32.31 \\
\hline F $98-173$ C & 7.42 & 1 & 8.99 & 1 & 16.41 \\
\hline F $98-58$ C & 7.12 & 1 & 9.50 & 1 & 16.62 \\
\hline Mean & 7.43 & & 14.37 & & \\
\hline $\begin{array}{l}{ }^{*} \text { Disea } \\
\text { L.S.D } \\
\text { L.S.D } \\
\text { L.S.D }\end{array}$ & $\begin{array}{r}\text { (S): } 0 . \\
\quad: \\
\quad:\end{array}$ & & & & \\
\hline
\end{tabular}

The statistical analysis showed that the differences between the two growth stages, genotypes and the interaction between them are significant.

Results in Table (3) appear the agronomic traits of chickpea genotypes of the second season. Results show that days to flowering, L 138 had the first arrangement followed by F $97-195 \mathrm{C}$ and G 88 as the same in the first season and the averages were $55.5,65.5$ and 69.3, respectively. In this respect, Murfet and Reid (1985) reported that the flowering genes influence maturity type and crop yield through their effects on the onset of reproduction, duration of reproductive phase, number of branches and number of flowers/node. On the other hand L138 and F 98 $233 \mathrm{C}$ maintained the first and second grades for the days of maturity as the first season followed by $\mathrm{G} 2$, F $98-233 \mathrm{C}$ and F 97- $195 \mathrm{C}$ with averages of 131.7, 141.7, 141.7, 141.7 and 141.7 days, respectively. In this respect, Summerfield and Robert (1988) reported that days to maturity in chickpea are untenable and generally breeders have used days to flowering as an indicator of crop duration. In practice, early flowering genotypes do not necessarily mature early and some late flowering genotypes have a short reproductive period and mature simultaneously with earlier flowering ones.

Sabaghpour et al. (2003) mentioned the importance of selection for early maturity chickpea to escape end of season drought due to lack of rainfall during flowering and seed filling. Also Monpara and Dhameliya (2013) stated that since early flowering leads to early onset of productive growth, combined selection for days to flowering and flowering period would enable more gain in improving earliness of crop maturity. Take into consideration of yield component, L 138 had the highest value of seed weight / plant followed by F 98 $-79 \mathrm{C}$ and $\mathrm{G} 2$ with averages of 10.28, 9.94 and 9.48 (g), respectively. Also in case of 100 seed weight, L138 had the first arrangement followed by F $95-$ $14 \mathrm{C}$ and $\mathrm{G} 88$ with averages of $24.51,23.93$ and $23.19(\mathrm{~g})$, respectively. In this respect, the highest values of seed weight / plant and 100- seed weight reflected on the seed yield/ feddan where L - 138 had the highest value of seed yield / feddan followed by G 88 and F 97 - $195 \mathrm{C}$ with averages of 5.11, 
4.63 and 4.36 ardab, respectively. Genotypes F $98-$ 173C, L 138 and F98 - 233 C had the highest values of plant height with averages of 63.0, 60.0 and 59.0 $\mathrm{cm}$., respectively. In case of number of capsules / plant, F 97 - $167 \mathrm{C}$ had the highest value followed by $\mathrm{F} 98-173 \mathrm{C}$ and $\mathrm{G} 1$ with averages of 46.05 , 42.95 and 41.04, respectively. Also, as it clear in the first season genotype G88 had the lowest values for plant height, number of branches/plant and number of capsules/plant (Table 3 ).

It can be noticed that Egyptian genotypes had the better values for number of capsules / plant, days for flowering, days for maturity, seed weight / plant (g), 100 seed weight $(\mathrm{g})$ and seed yield / feddan with averages of $23.42,72.27,140.10,8.56,21.97$ and 4.45 , respectively.

Table 3. Agronomic traits of some chickpea ( Cicer arietinum L.) genotypes under field conditions ( second season, $2010 / 2011$ ).

\begin{tabular}{|c|c|c|c|c|c|c|c|c|}
\hline $\begin{array}{l}\text { Parameter } \\
\text { Genotype }\end{array}$ & $\begin{array}{l}\text { Days for } \\
\text { flowering }\end{array}$ & $\begin{array}{l}\text { Days } \\
\text { for } \\
\text { maturity }\end{array}$ & $\begin{array}{l}\text { Plant } \\
\text { height } \\
\text { (cm.) }\end{array}$ & $\begin{array}{l}\text { No.of } \\
\text { branches/ } \\
\text { plant }\end{array}$ & $\begin{array}{l}\text { No.of } \\
\text { capsules/ } \\
\text { plant }\end{array}$ & $\begin{array}{l}100-\text { seed } \\
\text { weight } \\
\text { (g) }\end{array}$ & $\begin{array}{l}\text { Seed } \\
\text { weight/ } \\
\text { Plant (g) }\end{array}$ & $\begin{array}{l}\text { Seed } \\
\text { yield/ } \\
\text { feddan } \\
\text { (ardab) }\end{array}$ \\
\hline G 88 & 69.3 & 143.0 & 45.3 & 0.60 & 11.72 & 23.19 & 8.20 & 4.63 \\
\hline G 1 & 83.0 & 144.0 & 50.3 & 1.15 & 41.04 & 17.20 & 6.28 & 4.11 \\
\hline G 2 & 81.3 & 141.7 & 45.8 & 0.80 & 17.72 & 22.99 & 9.48 & 3.94 \\
\hline L 138 & 55.5 & 131.7 & 60.0 & 1.40 & 23.20 & 24.51 & 10.28 & 5.11 \\
\hline F $95-14$ C & 73.0 & 142.2 & 51.0 & 1.65 & 26.37 & 23.93 & 8.40 & 3.13 \\
\hline F $98-79$ C & 72.5 & 142.2 & 56.3 & 1.60 & 36.40 & 22.36 & 9.94 & 3.62 \\
\hline F $98-233$ C & 80.7 & 141.7 & 59.0 & 2.10 & 38.20 & 17.84 & 8.80 & 3.78 \\
\hline F $97-195$ C & 65.5 & 141.7 & 56.8 & 2.50 & 23.35 & 21.42 & 9.01 & 4.36 \\
\hline F $97-167$ C & 78.0 & 144.0 & 52.5 & 2.25 & 46.05 & 16.14 & 7.29 & 3.50 \\
\hline F $97-14$ C & 77.5 & 142.0 & 58.7 & 1.60 & 37.37 & 17.09 & 7.93 & 3.46 \\
\hline F $98-173$ C & 79.5 & 142.2 & 63.0 & 2.10 & 42.95 & 20.63 & 6.70 & 4.19 \\
\hline F $98-58 \mathrm{C}$ & 73.7 & 142.2 & 58.0 & 1.15 & 17.80 & 20.61 & 5.47 & 3.85 \\
\hline L.S.D. 0.05 & 3.96 & 3.19 & 1.01 & 0.27 & 2.90 & 1.25 & 0.83 & 0.49 \\
\hline
\end{tabular}

Generally results are closed to that of the first season where L - 138 had the highest genotypes in case of number of days to flowering, number of days to maturity, seed weight/plant (g), 100 - seed weight (g) and seed yield/feddan (ardab). These results are in agreement with the findings of Bastawisy et al. (2008) who reported that genotype Etay 38 gave the highest desirable significant for flowering and maturity date, number of capsules / plant and seed yield / plant. The other genotypes showed some differences in its arrangement compared with the first season.

Results in Table (4) show the disease incidence in the second season and it closed to that of the first one but with light differences in the arrangement of some genotypes. L 138 had the lowest value of the wilt incidence at the seedling stage with an average of $2.69 \%$ followed by F $97-195$ C, F $98-58$ C and G 88 with averages of $3.09,4.13$ and $4.40 \%$, respectively. The same trend was noticed at the podding stage where the disease incidence was the lowest in case of L 138 followed by F $97-195$ C, G 88 , F $98-58 \mathrm{C}$ and F $98-173 \mathrm{C}$ with averages of $5.67,6.46,7.48,8.67$ and $8.86 \%$, respectively. The lowest total wilt incidence was noticed with L 138 , F $97-195 \mathrm{C}$ and $\mathrm{G} 88$ with averages of $8.36,9.55$ and $11.88 \%$, respectively. The Egyptian genotypes at seedling and podding stages ranged between $2.69-$ $7.92 \%$ and $5.67-17.87 \%$, respectively, but in case of ICARDA genotypes it range from 3.09 to $9.46 \%$ and $6.46-26.36 \%$, respectively. The statistical analysis showed that the differences between the growth stages, genotypes and the interaction between them are significant.

Variation of Fusarium oxysporum f.sp.ciceris linear growth on the media containing chickpea genotypes leaf and root extracts was determined under laboratory conditions (Table 5). Generally, the fungal growth was maximum on the media containing roots extract as compared to leaves extract and these results are in agreement with the findings of Ahmad (2010) who mentioned that this proves soil borne nature of F.oxysporum f.sp.ciceris. Mycelial growth range from 2.05 to $4.84 \mathrm{~cm}$. on the media mixed with leaf extracts and from 2.86 to $8.52 \mathrm{~cm}$. on the others mixed with root extracts. Also, it can be noticed that the leaf and root extracts of the Egyptian cultivars; G 88, G1, G2 and the genotype L 138 had low fungal linear growth and it range from 2.05 to $4.73 \mathrm{~cm}$. and 2.86 to $5.97 \mathrm{~cm}$., respectively. On the other hand the genotypes obtained from ICARDA, it had more fungal linear growth than the Egyptian genotypes where it range from 2.53 to 4.84 $\mathrm{cm}$. and $3.62-8.52 \mathrm{~cm}$. for leaf and root extract, respectively. The minimum mycelia growth of F.oxysporum f.sp.ciceris may be refer to the probability of its resistance to the wilt disease caused by this fungus and the maximum fungal growth to its susceptibility. These results are in agreement with the findings of Rahber- Bhatti (1986), Mukhtar 
(2007) and Ahmad (2010) who reported that in some susceptible genotypes, fungal growth enhanced while in some other genotypes it was reduced and this might be due to some antagonistic properties in plants against diseases. The low fungal linear growth on the media containing leaf extracts (CLE) was noticed with L 138, F 97 - 195 C, F97 - 167 C and G 88 with averages of $2.05,2.53,3.66$ and $3.67 \mathrm{~cm}$., respectively. In case of roots extract, L 138, F 97 195 C, F $98-173$ C and G 1 had the lesser linear growth than the other genotypes with averages of $2.86,3.62,4.19$ and $5.38 \mathrm{~cm}$., respectively. In this respect, Rahhal et al. (1999) reported that chickpea entries shoot and root extracts had different effect on the linear growth of Sclerotinia sclerotiorum and the number and diameter of sclerotia / plate. The statistical analysis showed that there are significant differences between the two extracts, genotypes and the interaction between them.

Table 4. Disease incidence of fusarium wilt on various chickpea (Cicer arietinum L.) genotypes at two growth stages ( field experiment 2010 / 2011).

\begin{tabular}{|c|c|c|c|c|c|}
\hline \multirow{3}{*}{ Genotype } & \multicolumn{4}{|c|}{ Disease incidence } & \multirow{3}{*}{ Total wilt $\%$} \\
\hline & \multicolumn{2}{|c|}{ Seedling stage } & \multicolumn{2}{|c|}{ Podding stage } & \\
\hline & Wilt \% & $\mathrm{DR}^{*}$ & Wilt \% & DR & \\
\hline G 88 & 4.40 & 1 & 7.48 & 1 & 11.88 \\
\hline G 1 & 7.92 & 1 & 16.68 & 3 & 24.60 \\
\hline G 2 & 6.55 & 1 & 17.87 & 3 & 24.42 \\
\hline $\mathrm{L}-138$ & 2.69 & 1 & 5.67 & 3 & 8.36 \\
\hline F $95-14$ C & 6.02 & 1 & 11.25 & 5 & 17.27 \\
\hline F $98-79$ C & 9.46 & 1 & 26.36 & 5 & 35.82 \\
\hline F $98-233$ C & 6.02 & 1 & 20.38 & 1 & 26.40 \\
\hline F $97-195$ C & 3.09 & 1 & 6.46 & 3 & 9.55 \\
\hline F $97-167$ C & 5.68 & 1 & 12.02 & 5 & 17.70 \\
\hline F $97-14$ C & 7.27 & 1 & 22.02 & 1 & 29.29 \\
\hline F $98-173$ C & 5.00 & 1 & 8.86 & 1 & 13.86 \\
\hline F $98-58 \mathrm{C}$ & 4.13 & 1 & 8.67 & 1 & 12.80 \\
\hline Mean & 5.69 & & 13.67 & & \\
\hline $\begin{array}{l}\text { *Diseas } \\
\text { L.S.D. } \\
\text { L.S.D. } \\
\text { L.S.D. }\end{array}$ & $\begin{array}{r}(\mathrm{S}): 0.51 \\
: 1.2 \\
:\end{array}$ & & & & \\
\hline
\end{tabular}

Table 5. Effect of chickpea genotypes leaf extracts (CLE) and root extracts (CRE) on Fusarium oxysporum f.sp.ciceris linear growth (in vitro).

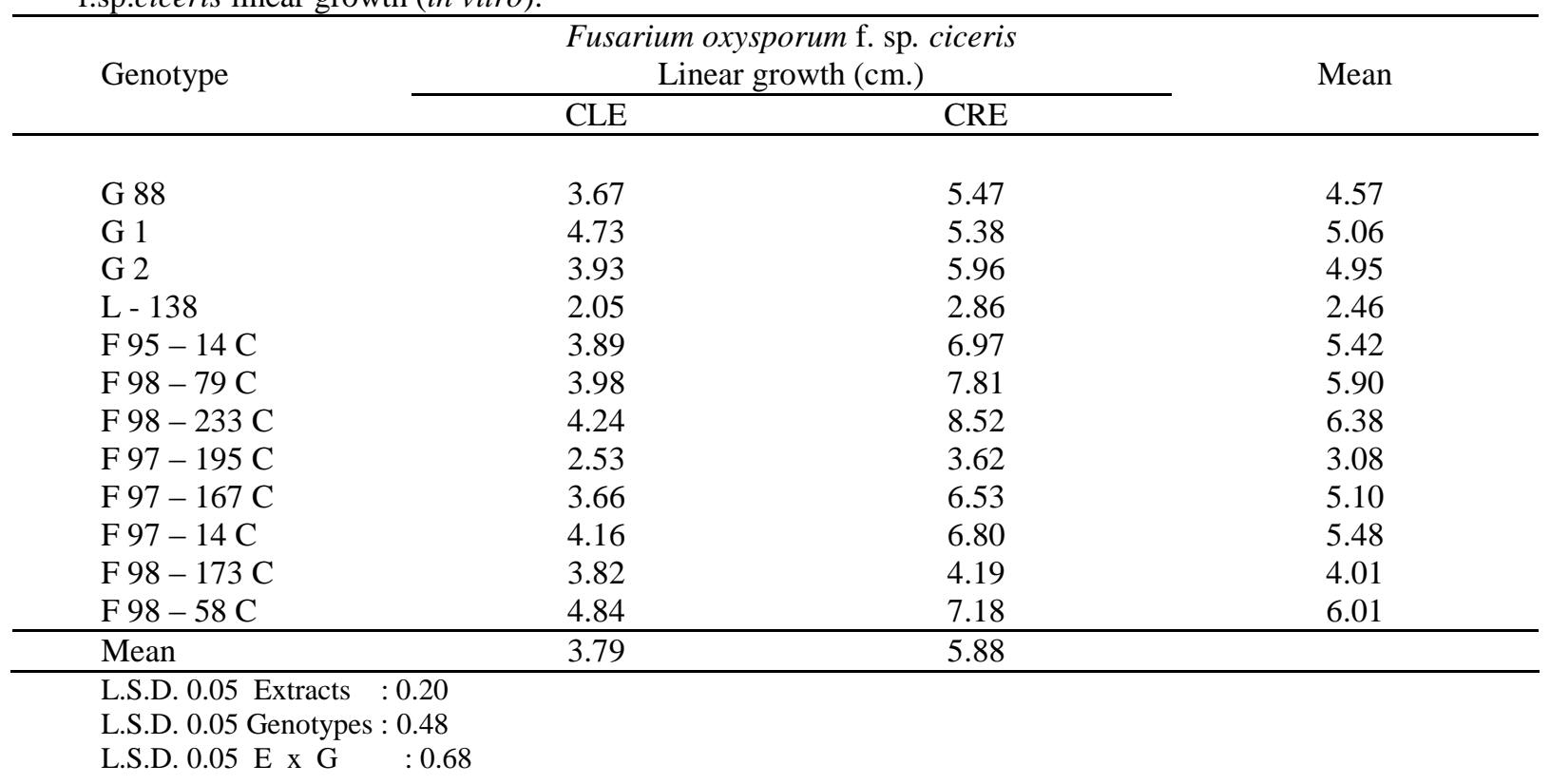

From the previous tables it is clear that $\mathrm{L} 138$ is a potential genotype for release in the chickpea producing area because of its higher seed weight/plant $(\mathrm{g}), 100$ seed weight $(\mathrm{g})$ and seed 
yield/feddan (ardab) in addition to its earlier flowering and maturity and its resistance to fusarium wilt than the other genotypes which had different arrangements for the tested agronomic traits.

\section{References}

Ahmad, M. A. (2010): Variability in Fusarium oxysporum f.sp.ciceris for chickpea wilt resistance in Pakistan. Ph.D. Fac. Biological Sciences, Quaid-i. Azam Univ., Islam abad, Pakistan, pp. 162.

Ahmad, M. A.; S. M. Iqbal; Najma, Ayub; Yasmin, Ahmad and A. Akram (2010): Identification of resistant source in chickpea against fusarium wilt. Pak. J. Bot., 42 (1): 417 - 426.

Bakhsh, A.; S. M. Iqbal and I. K. Haq (2007): Evaluation of chickpea germplasm for wilt resistance. Pak. J. Bot., 39 (2): 583 - 593.

Barhate, B. G.; G. N. Dake; B. C. Game and D. N. Padule (2006): Variability for virulence in Fusarium oxysporum f.sp.ciceri causing wilt of chickpea. Legume Res. 29 (4): 308 - 310.

Bastawisy, M. H.; A. A. Hamada; A. A. El-Hosary; A. M. El-Garhy; S. A. A. Attia; Sohir, A. Zeinel Abdein; R. M. Khalaf; S. B. Ragheb and M. M. Omran (2008): Phenotypic and genotypic stability for earliness, yield and its components in some chickpea genotypes. Minufiya J. Agric. Res. 33 (3): 777 - 795.

Bhatti, I. M. and A. T. Soomro (1996): Agricultural inputs and field crop production in Sindh. Agricultural Research Sindh, Hyderabad.

Chaudhary, M. A.; M. B. Ilyas; F. Muhammad and M. U. Ghazanfar (2007): Sources of resistance in chickpea germplasm against fusarium wilt. Mycopath., 5 (1): $17-21$.

Elfatih, M.; K. Ali; S. Inanaga and Y. Sugimoto (2002): Source of resistance to fusarium wilt of chickpea in Sudan. Phytopathol. Mediterr.,41: $163-169$.

Emenky, F. A. O. and A. S. Khalaf (2008): Effect of sowing depths and seed size of some winter cultivars of chickpea (Cicer arietinum L.) on field emergence and vegetative growth. Res. J. Seed Sci. 1 (1): $11-18$.

FAOSTAT data (2006): htt://: faostat.fao.org/faostat.

Haware, M. P. and Y. L. Nene (1980): Influence of wilt at different stages on yield loss in chickpea. Tropical Grain legume Bulletin. 19: 38 - 44.

Haware, M. P.; Y. L. Nene and S. B. Mathur (1986 a): Seed borne diseases of chickpea. Technical Bulletin. Danish Government Institute of Seed Technology for Developing Countries. Copenhagen, 1: 1 - 32 .

Haware, M. P.; Y. L. Nene and M. Natrajan (1986 b): Survival of Fusarium oxysporum f.sp.ciceri in soil in absence of chickpea. Paper presented in the National Seiminar on Management of soil borne diseases of crop plants Proc. Natn. Sem. 8
- 10 Jan. 1986, Tamilnadu Agricultural Univ., Coimbatore, Tamilnadu India.

Haware, M. P.; Y. L. Nene; R. P. S. Pundir and J. Narayana (1992): Screening of world chickpea germplasm for resistance to fusarium wilt. Field Crops Res. 30: 147 - 154.

Huisman, J. and A. F. B. Venderpoel (1994): Aspect of the nutritional quality and use of cool season food legume in animal food. Pp. $53-57$.

Hulse, J. A. (1991): Nature composition and utilization of legumes, pp. $11-27$.

Iqbal, S. M.; C. A. Rauf; A. Bakhsh and U. Iqbal (2005): Variability in F.oxysporum f.sp.ciceris. Mycopath. $3(1-2)$ : $47-51$.

Johansen, C.; D. N. Singh; L. Krishnamurthy; N. P. Saxena; Y. S. Chauhan and J. V. D. K. Kumar Rao (1997): Option for alleviating moisture stress in pulse crops. In A. N. Asthana and Masood Ali (Eds.) " Recent Advances in Pulses Research", pp. 425 - 442. Indian Institute of Pulses Research, Indian Society of Pulses Research and Development, Kanpur, Uttar Pradesh, India.

Kumar, J. and A. Abbo (2001): Genetics of flowering time in chickpea and its bearing on productivity in semiarid environment. Advances in Agronomy, 72: 107 - 138.

Kumar, J.; S. C. Sethi; C. Johansen; T. G. Kelley; M. M. Rahman and H. A. Van Rheenen (1996): Potential of short - duration chickpea varieties. Ind. J. Dryland Agric. Res. Dev. 11: 28 - 32.

Mahmood, K.; M. Saleem and A. Ahsan (2011): Inheritence of resistance to fusarium wilt in chickpea. Pak. J. Agric. Sci., 48: 55 - 58.

Monpara, B. A. and H. R. Dhameliya (2013): Genetic behavior of earliness related traits and seed yield in chickpea (Cicer arietinum L.). Pakist. J. Biol. Sci. 16 (18): 955-959.

Mukhtar, I (2007): Comparison of phytochemical and chemical control of Fusarium oxysporum f.sp.ciceris. Mycopath., 5 (2): 107 - 110.

Murfet, I. C. and J. B. Reid (1985): "The Control of Flowering and Internode Length in Pisum" In P. D. Hebblethwaite, M. C. Heath, T. C. K. Dawkins (Eds.), The Pea Crop: "A Basis for Improvement " pp. 67 - 80. Butterworths, London.

Navas - Corte's, J. A.; B. Hau and R. M. Jime'nez Diaz (2000): Yield loss in chickpea in relation to development of fusarium wilt epidemics. Phytopathology, 90(11): 1269 - 1278.

Nene, Y. L. and M. P. Haware (1980): Screening chickpea for resistance to wilt. Pl. Dis. 64: $379-$ 380.

Nikam, P. S.; G. P. Jagtap and P. L. Sontakke (2007): Management of chickpea wilt caused by F.oxysporum f.sp.ciceris. African J. Agric. Res. 2(12): $692-697$. 
Or, E.; R. Hovav and S. Abbo (1991): A major for flowering time in chickpea. Crop Sci. 39: 315 332.

Rahber - Bhatti, M. H. (1986): Control of Phakopsora grewiae with plant diffusates. Pak. J. Bot., 18(2): 329 - 333.

Rahhal, M. M. H.; S. H. Mansour and M. S. A. Mohamed (1999): Evaluating chickpea entries for resistance to Sclerotinia sclerotiorum under field and greenhouse conditions. Minufiya J. Agric. Res., 24(5): 1583 - 1593.

Ryan, J. G. (1997): A global perspective on pigeonpea and chickpea sustainable production systems: Present status and future potential. In A. N. Asthana and Masood Ali (Eds.), "Recent Advances in Pulses Research" pp. 1 - 31. Indian Society of Pulses Research and Development, Indian Institute of Pulses research (IIPR), Kanpur, india.

Sabaghpour, S. H.; E. Sadeghi and R. S. Malhotra (2003): Present status and future prospects of chickpea cultivation in Iran. International Chickpea Conference. 20 - 22 Jan., Raipur, India.

Sabaghpour, S. H.; A. A. Mahmodi; A. Saeed; M. Kamel and R. S. Malhtra (2006): Study on chickpea drought tolerance lines under dryland conditions of Iran. Indian J. Crop Science, 1 (1 2): $70-73$.

Sandhu, S.; S. K. Gupta; P. M. Gaur; A. K. Saxene; S. Sharma and P. Kaur (2007): Studies on early podding varieties and post - harvest management of immature green grains of chickpea to be used as vegetable. Acta Hort. 752: $353-358$.

Sharma, K. D. and F. J. Muehlbauer (2007): Fusarium wilt of chickpea physiological specialization, genetics of resistance and resistance gene tagging. Euphytica. $157(1-2)$ : 1 -14 .

Snedecor, G. W. and W. G. Cochran (1981): Statistical Methods. $7^{\text {th }}$ Edition, Iowa State Univ. Press. Ames, Iowa, USA.

Summerfield, R. J. and E. H. Roberts (1988): Photothermal regulation of flowering in pea, lentil, faba bean and chickpea. In: World Crops Cool Season Food Legumes, Summerfield, R. J. (Ed.). Kluwer Academic Publishers, Dordecht, The Netherlands, pp: $911-922$.

Worland, A. J. (1996): The influence of flowering time genes on environmental adaptability in European wheats. Euphytica, 89: 49 - 57.

$$
\begin{aligned}
& \text { تقييم بعض التراكيب الوراثيه للحمص لصفات التبكير والمحصول ومكوناته ومقاومة الذبول الفيوزاريومى } \\
& \text { 1عادل الجارحى محمد , محمد مجدى حمزه رحال } \\
& \text { 1- قسم بحوث المحاصيل البقوليه - معهد بحوث الدحاصيل الحقليه - مركز البحوث الزراعيه - الجيزه }
\end{aligned}
$$

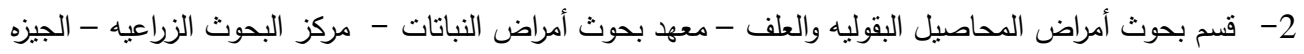

أجريت هذه الدراسه خلال موسمى الزراعه 2010/2009 , 2010/ 2011 بمحطة البحوث الزراعيه بإيتاى البارود لتقييم 12 نركبب

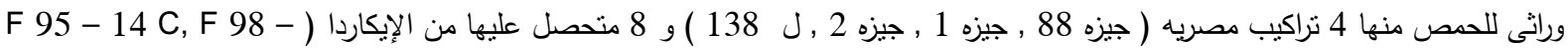
(79 C, F 98 - 233 C, F 97-195 C, F 97 - 167 C , F 97- 14 C, F 98 - 173 C , F 98 - 58 C والمحصول ومكوناته ومقاومة الذبول الفيوزاريومى تحت الظروف المعمليه والحقليه.

بصورة عامه تنين من قيم النتائج المحصوليه للموسمين أن التركيب الوراثى ل 138 إحنل المرتبه الأولى فى صفية التبكير ( عدد الأيام

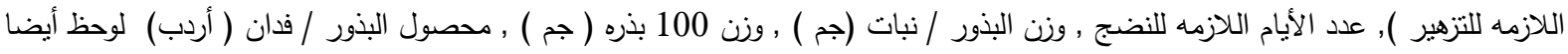

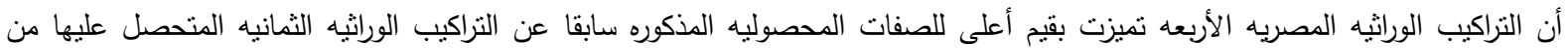
الإيكاردأ0 تحت الظروف الحقليه وجد أنه فى الموسم الأول كان أقل نسبة ذبول فيوزاريومى خلال خلال مرحلتى البادره وتكوين الكبسولات فى الكى

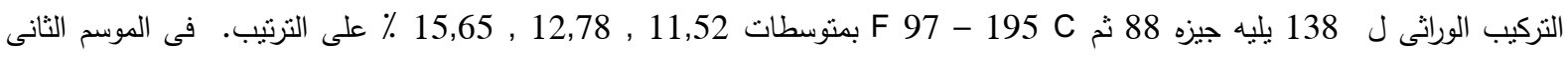

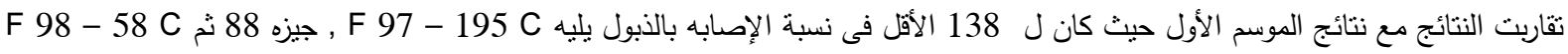
بمنوسطات 8,36 , 9,55 , 11,88 , 12,80 \% على التزتيب.

أظهر التركيب الوراثى ل 138 نتكيرا ملحوظا للتزهير والنضج بالإضافه لزياده فى وزن البذور / نبات, وزن 100 بذره, محصول البذور / البهات

فدان وكذلك أظهر مقاومه لابأس بها للذبول الفيوزاريومى · لذلك يعتبر من التراكيب الوراثيه المبشره ويجب الإهتمام به وإكثاره لإدخاله ضمن إنبرن الأصناف التجاريه . 